Article

\title{
Fostering Resilience and Adaptation to Drought in the Southern High Plains: Using Participatory Methods for More Robust Citizen Science
}

\author{
Jacqueline M. Vadjunec ${ }^{1, *}\left(\mathbb{D}\right.$, Nicole M. Colston ${ }^{2}$, Todd D. Fagin $^{3}$, Austin L. Boardman $^{1}\left[\right.$ and Brian Birchler ${ }^{1}$ \\ 1 Department of Geography, Oklahoma State University, Stillwater, OK 74078, USA; \\ austinboardman@gmail.com (A.L.B.); brian.birchler@okstate.edu (B.B.) \\ 2 Department of Natural Resources and Ecology Management, Oklahoma State University, Stillwater, OK 74078, \\ USA; nicole.colston@okstate.edu \\ 3 Center for Spatial Analysis, University of Oklahoma, Norman, OK 73019, USA; tfagin@ou.edu \\ * Correspondence: Jacqueline.vadjunec@okstate.edu
}

Citation: Vadjunec, J.M.; Colston, N.M.; Fagin, T.D.; Boardman, A.L.; Birchler, B. Fostering Resilience and Adaptation to Drought in the Southern High Plains: Using Participatory Methods for More Robust Citizen Science. Sustainability 2022, 14, 1813. https://doi.org/ $10.3390 /$ su14031813

Academic Editors: Barbora Duží, Jakub Trojan, Eglè Butkevičienè and Bálint Balázs

Received: 31 December 2021

Accepted: 31 January 2022

Published: 5 February 2022

Publisher's Note: MDPI stays neutral with regard to jurisdictional claims in published maps and institutional affiliations.

Copyright: (c) 2022 by the authors. Licensee MDPI, Basel, Switzerland. This article is an open access article distributed under the terms and conditions of the Creative Commons Attribution (CC BY) license (https:// creativecommons.org/licenses/by/ $4.0 /)$.

\begin{abstract}
Citizen science holds the potential and capacity to change the role of science in the face of current and impending environmental sustainability challenges. However, the sustainability science community must also address the ethical challenges inherent in the nature and outcomes of citizen participation and inclusion. In this article, we provide a brief history of Participatory Action Research (PAR), long popular in the social sciences, and explain how participatory methods can inform the process and products of citizen science to meet the dueling ideals of ethically engaging communities and producing more robust science. Our decade of human-environment research on drought resilience and adaptation in the Southern High Plains of the United States illustrates how PAR complements formal science and can contribute to community resilience and adaptation efforts. Synthesized into 10 entry points for more ethical and participatory science, our semi-chronological narrative offers concrete strategies informed by PAR principles and values, at various stages of research, and highlights the place-based, ethical, and methodological contexts for applying each strategy.
\end{abstract}

Keywords: citizen science; drought; grasslands; Ogallala Aquifer; participatory methods; research ethics; social and environmental justice; socioecological resilience; Southern High Plains; USA

\section{Introduction}

The incorporation of everyday people into the scientific process, or "citizen science," was first proposed by sociologist Alan Irwin in 1995. Irwin [1] pressed for the democratization of science, for people, by people, and for the common good. Irwin's "citizen science" promised to benefit everyday citizens via addressing social and environmental justice and sustainability issues. At the same time, it would also benefit science, which was in the midst of a paradigmatic and existential crisis, having been taken to task for its often elite and exclusive status [2]. Citizen science has grown rapidly over the last decade with the creation of both the Citizen Science Association (CSA) in the United States and the European Citizen Science Association (ECSA). In the United States, the growth of citizen science was responsible in large part by work through the Cornell Ornithology $\mathrm{Lab}$ [3]. In general, the bulk of recent citizen science looks and sounds different from Irwin's initial conceptualization of citizen science, which was grounded in the social sciences. In particular, the theory and tool kit rapidly expanded in the natural sciences [4].

Citizen science is diverse, unruly, and symbolizes many different things to different people [5]. Since a large part of citizen science is produced within the natural sciences, it is often seen as an investment in future scientists by supporting STEM education [6]. For others, education via citizen science is an emancipatory act, or a means to address social justice concerns and inclusiveness, as science performed for and by people. For some 
researchers and politicians, citizen science is a way to make science and research more directly relatable to taxpayers, funders, and everyday people [7]. It is also a means to get more out of our research, as citizen scientists can be low- or no-cost helpers. Theobald and colleagues [8] estimate that citizen scientists contribute $\sim \$ 2.5$ billion annually in no-cost labor. Theoretically, it makes communities of researchers and everyday citizens able to conduct more research for lower costs, thus giving us the ability to solve more of the wicked problems facing society [9].

Since the early 2010s, citizen science has grown rapidly, veering greatly from Irwin's 1995 [1] initial manifestation. Recently, there has been a rapid growth in associations, journals, academic programs, certificates, and crowdsourcing sites such as SciStarter. Funding has also increased, with most government agencies now promoting citizen science-related programs and opportunities. Future Earth [10], an international research program for global sustainability, calls for transdisciplinary research and the coproduction of knowledge via "extreme citizen science" (www.futureearth.org, accessed on 30 June 2021). Future Earth is heavily co-funded by over 70 countries, including the US and others. Given the win-win scenario for science and people, the possibilities for citizen science are seemingly endless. The UNESCO Science Commission recently adopted an Open Science Recommendation for global policy and regulatory agendas [11]. Here, citizen science is conceptualized as a process of Open Science that might strive to collect, aggregate, and share data in ways that advances social and environmental resilience. The model of elevating individuals beyond volunteering to engaged participation is proposed to democratize science by involving the public [12].

The inherently technology-driven and data-driven relationship between citizen science and open science raises many unresolved questions regarding accessibility, transparency, and transdisciplinarity [13]. New and emerging geographic and geospatial technologies continue to play a significant role in expanding the processes and practices of citizen science, such as digital automation, metadata, mobile applications, machine learning, and artificial intelligence. The prevalence of mobile devices, remote sensing, wireless sensor networks, and other types of technologies has created an immense amount of volunteered geographical data [14], while raising significant issues of privacy, security, and ethics, which need to be addressed [15]. Despite the promise of emerging technologies for real time and big data, it is prudent to slow down and examine processes that might generate new injustices or exacerbate patterns of exclusion or invisibility [16]. Citizen science also needs to distinguish the process of open participation from the products of research that act independently as instruments of social, cultural, and political power. For this reason, researchers should involve participants in deciding how data is shared and with whom it is shared [17].

While approaches for volunteer involvement in citizen science vary widely (see [18]), citizen science has been broadly questioned by scientists regarding the efficacy of the research, mainly due to the potential for sampling biases and/or data collection errors [19]. Conversely, some researchers have raised concerns regarding the fairly traditional topdown approach of many citizen science projects, which tend to be driven by people who were trained in traditional science paradigms [20], as well as the extractive nature of the exchange and the potential for abuse [21]. Other ethical debates have ensued regarding data privacy, the protection of citizen scientists [22,23], a need for true coproduced research, and equity and inclusion among various actors [24]. We argue that Participatory Action Research (PAR), as an older but parallel approach used predominantly in education and the social sciences, offers a complementary means for addressing some of these ongoing ethical concerns.

\section{Complementary and Parallel Approaches of Participatory Action Research (PAR)}

PAR and related participatory research approaches, in general, share inspiration from John Dewey's pragmatic call to participatory democracy and direct action in the 1930s [25,26], along with Kurt Lewin's [27] arguments that everyday people should be more 
involved with relevant decision-making [28]. Paulo Freire's landmark book [29] Liberation Theology pressed for human-centered approaches to addressing social issues as core ethical and educational issues, greatly inspiring the central tenets of PAR. Though springing out of Latin American Catholicism, liberation theology pressed for on-the-ground action over religious proselytizing when it came to dealing with society's most marginalized and downtrodden. Freire [29] (p. 45) noted contradictions between the oppressor and the oppressed (e.g., teacher and student, researcher and researched), arguing that liberation should not be a "gift" given to the oppressed, but rather should be viewed as a "mutual process" shared in true "solidarity." PAR has roots embedded in Freire's philosophy of ethics/humanization theory. By the 1980s, PAR and related participatory approaches, which sought to be collaborative, non-paternalistic, and diverse [30], were adopted heavily by social scientists and expanded globally to address both environmental and social justice and socioecological resilience concerns. PAR approaches are inclusive, seeking a diversity of people and stakeholder groups, often throughout the lifecycle of the entire research process.

Building from the foundational teachings of Freire, a PAR approach privileges neither the researcher nor the researched. Instead, PAR approaches generally take a more bottomup approach, seeking equity and inclusion of all participants. PAR approaches also tend to place value on local cosmologies, seeking to "give voice" to Traditional Environmental Knowledge (TEK) on a community's terms [31-34]. Such approaches have been heavily adapted by practitioners working on the nexus of environment and development [35,36], common property natural resource governance [37,38], adaptive comanagement in the face of climate change [39,40], and community health [41], among others. We argue that Irwin's [1] original version of citizen science was written in the spirit of PAR. However, citizen science's PAR antecedent roots appear to have been largely forgotten, lost in the process of the institutionalization of citizen science.

PAR approaches, however, are not without their limitations. Smith and colleagues [42] (p. 414) discuss the inevitable challenges associated with participatory methods, noting tensions between the ideal of PAR and the reality of PAR, an often tricky process that they describe as "designing the plane while flying it." Grant and colleagues [43] (p. 591) identify primary PAR challenges wrapped around "building relationships, acknowledging, and sharing power, encouraging participation, making change, and establishing credible accounts." Lastly, Harrison [44] notes particular difficulties using PAR methods in combination with high technology among the lay community. Challenges notwithstanding, we argue that PAR approaches offer a complementary and much needed way to "humanize research" [45], which is especially important in tandem with the increasing tech savviness of application-based citizen science approaches and the resultant challenges discussed above.

Here, we offer a semi-chronological narrative of a decade of human-environment research on drought resilience and adaptation in the High Plains of the United States. Highlighting strategies from our own project, we discuss ten entry points for incorporating participatory action research with citizen science approaches for increasing socioecological resilience. We conclude by discussing the advantages and disadvantages of using a PAR approach. We argue that, taken together, PAR and citizen science approaches can make socioecological studies more robust.

\section{Background and Methods}

Situating PAR within "No Man's Land"

Our research, a comparative study regarding socioecological resilience and adaptation to drought in the Southern High Plains, took place in and around the Oklahoma Panhandle, previously called No Man's Land, starting with two counties (Cimarron County, OK, USA, and Union County, NM, USA) and expanding over time in various capacities to the "Five States Area": Oklahoma, New Mexico, Colorado, Kansas, and Texas (See Figure 1). This region is largely agricultural with a long history of recurrent drought (such as the Dust Bowl of the 1930s) and a complex web of local, regional, state, and federal land and water policies [46]. Research began in 2008, when the lead author started working in the 
region recording oral histories with Dust Bowl survivors. Inspired by their life stories, as well as the lead author's previous PAR related experience in the tropics, the research team began a National Science Foundation (NSF) funded project (2013) related to drought adaptation, land-use practices, and governance. Various projects built off of this initial comparative two-county research project, including a 2018 USDA funded, comparative, citizen science and participatory project on regional agroecological resilience, as well as a citizen science precipitation monitoring program (see https:/ / arid.nmsu.edu and also http: / / www.spottyrain.org/, accessed on 29 December 2021). The scientific results of this mixed-method research project have been widely published elsewhere and include research related to drought perception [47], irrigation and water security [48], household land use and survivability [49], overgrazing [50], and woody plant encroachment [51], among others. Here, drawing on over a decade of ethnographic field experience that led to the above publications, we explore how participatory approaches to research can help serve larger research project needs, bolstering community trust, while supporting our more recent foray into citizen science-based research [52]. We weave these fieldwork experiences into 10 entry points for participatory methods in citizen science.

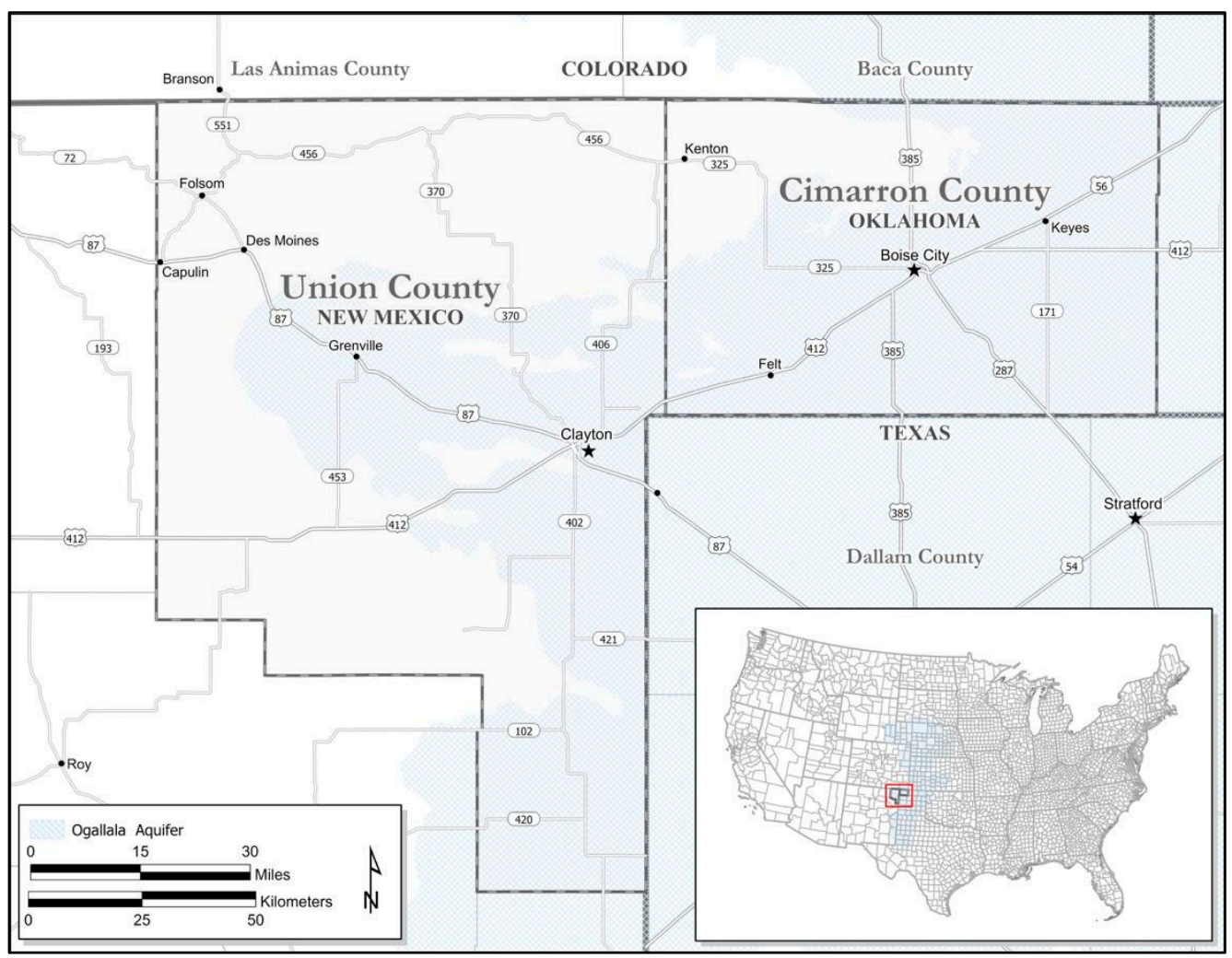

Figure 1. Map of the Study Area. Source: Figure created by the authors using data from the U.S. Census Bureau.

With a shared frontier history and similar climates, biophysical environments, agricultural economies, and demographic compositions [50,53], Cimarron County, OK, USA and Union County, NM, USA make an ideal region for comparative governance research. Both share a history of recurrent drought, experiencing six major drought events over the past 120 years, including the Dust Bowl of the 1930s [54] and a recent severe drought that lasted from approximately 2000 to 2015 [55]. This shared drought history has shaped the attitudes, perceptions, and outlooks of those who call this region home, especially as they relate to land and water management.

While the region has a long, storied history of Native American occupancy, EuroAmerican settlement of the region dates to approximately the 1870s [56,57]. In the 20th 
century, both Oklahoma and New Mexico emerged as important ranching and crop producing regions for the United States [54,58]. While populations of the two counties steadily decreased after the Dust Bowl, their importance as an agricultural region has persisted. Today, both are rural, sparsely populated counties with similar population densities ( 0.43 persons $/ \mathrm{km}^{2}$ [59]). Culturally, area residents are considered aging, hardworking and tenacious, predominantly Christian, and conservative, with a healthy distrust of both government and science.

Biophysically, the counties encompass a transition zone where "the Rocky Mountains meet the short grass prairie" [60]. A large portion of the study area is underlain by the High Plains Aquifer System (HPA), with center pivot irrigation use increasing dramatically starting in the 1980s [48]. Much of the study area is also within the Cimarron River watershed. These biophysical factors have contributed to the two counties' rise as an important agricultural region in the nation. Of an estimated 2.98 million acres of farmland distributed throughout the two counties, $83 \%$ are pastureland and $16 \%$ are cropland. The predominant crops grown in the two counties include wheat, winter wheat, corn, sorghum, and forage. Cattle and calves are by far the top livestock commodities in the two counties [61]. However, agricultural operations are regularly impacted by drought, woody plant encroachment, and other natural hazards which can cause environmental and economic challenges for farmers and ranchers [51,52].

Cimarron and Union counties are biophysically, demographically, culturally, and economically similar, but the two counties are subject to differing local, regional, state, and federal land and water policies. For example, local and regional groundwater policies vary across the two counties. In Oklahoma, groundwater is regarded as private property and is governed under prior appropriation, yet subject to reasonable regulation by the local district's water resource board [48]. By contrast, groundwater usage in New Mexico is under the jurisdiction of the state and groundwater permits are issued under the control of the State Engineer [48]. Similarly, state and federal land policies are highly contested and differentially influence agricultural producers' land-use decisions, and consequent land-cover and vegetation dynamics, processes, and feedbacks, henceforth called landuse/land-cover change (lulcc) [46,50,62]. Furthermore, at the federal level, producers are often dependent on agricultural subsidies and incentives, such as voluntary conservation programs (e.g., the Environmental Quality Incentives Program [EQIP] and the Conservation Reserve Program [CRP]). These programs and incentives influence land management decisions and, ultimately, land-cover dynamics and water resource use, often with unintended consequences such as increased water usage [63] and increased land user vulnerability [37]. Commodity subsidies may actually incentivize the cultivation of water-intensive crops (e.g., corn) in areas once dominated by dryland farming. From 1995 to 2021, corn subsidies topped more than 65.8 million USD for both counties jointly [64].

Given the dynamic, contested, and differential impacts of policy and climate on socioecological resilience in the region, our larger research agenda broadly sought to understand how landowners perceive environmental hazards (such as drought) both past and present, what actions landowners take to mitigate these hazards, and how these adaptations/mitigations impact agriculture and socioecological sustainability throughout the region. Given the profoundly human nature of this work, our research design implemented participatory and mixed-method transdisciplinary approaches. Below, we share lessons from our work in the hope of inspiring a more ethical and engaged vision of citizen science.

\section{Results and Discussion}

\subsection{Ten Entry Points for Participatory Methods in Citizen Science}

Without a doubt, contemporary definitions of citizen science are historically contextualized within an evolving theory of coproduction between science and society. Broadly, the concept of coproductive capacities suggests mechanisms for improving citizen science processes and practices through diverse participation and attention to the underlying histories, contexts, preconceptions, experiences, and relationships between science and society. The 
practical understanding of coproduction demands active facilitation and management of participatory processes $[65,66]$. There are decades of research by diverse scholars in communication, educational sciences, psychology, sociology, political science, anthropology, and geography in the cooperative processes and decision-making procedures to support the need for (and limitations of participation in research and practice regarding sustainability issues $[7,67,68]$. Indeed, the continued sharing of lessons concerning what works, what does not, and how to best support coproductive capacities is "clearly an on-going task" [66] and the question always remains: what process works in this context [69]?

In this section, we provide 10 entry points for more ethical and participatory approaches to building coproductive capacity and socioecological resilience within and outside of citizen science projects [20]. We offer strategies informed by PAR principles and values, followed by examples from our own research. As a semi-chronological narrative of various aspects and publications related to our larger overall research project, this section illustrates how to incorporate PAR at various stages of research and highlights the place-based, ethical, and mixed-methodological contexts for applying each strategy. In each section, we review relevant literature for each approach, along with an account of our own experiences. While situating the possible entry points for participatory methods in citizen science within our own core research work and experiences, we hope to illustrate ways that diverse field and community-based research projects might benefit from such approaches.

\subsubsection{Develop Questions and Deliverables with Communities}

The participation of communities in shaping the research questions, outcomes, and deliverables is a fundamental principle of PAR. However, in contemporary terms, "cocreated" participatory models for citizen science that include community at all stages of inquiry are rarely the norm $[18,70]$. Indeed, participatory methods inherently struggle with limits to full citizen participation, practical challenges to cooperation among stakeholders, and a host of ethical issues related to sharing and using data [71]. Still, the lack of alignment between community priorities and research agendas may limit diverse participation in citizen science in the United States [72]. Simply put, alignment is achieved by involving the community at all stages of research and placing scientific knowledge alongside other ways of knowing [73]. The benefits can also include more robust science.

It is important to value local knowledge, historical accounts, and participant observations in addition to research data [74]. In the case of our project, the opportunity to talk with members of the community in advance of the research study produced a better set of research questions, based on land managers' real-time observations related to drought. In 2008, the project leader conducted an initial (small n) set of oral histories with the Oklahoma State University Library Oral History Project that set the context for the larger project described above. These initial oral histories were focused on the 1930s drought, while current drought was clearly impacting the community. This opportunity and these discussions provided the initial observations regarding short- and long-term resilience, land use, governance, and drought impacts. Our initial research questions ultimately arose from those rich discussions on community wants and needs. Before applying for funding, the principal investigators participated in multiple community meetings in a variety of informal venues (senior lunches, community events, etc.) to develop, adjust, and hone in on the project's ultimate research questions.

At the beginning of the project, we invited community members to help delineate local issues, perspectives, and perceptions related to socioecological resilience. These preliminary forms of engagement help to build trust and mediate insider-outsider tensions, while tapping into local knowledge via researcher-community partnerships. Discussing community issues related to drought while focusing on tangible community needs (i.e., deliverables) helped us to develop our research questions, while paying close attention to the "so what?" question that is key to community buy-in. Considering the community's desired deliverables upfront helped structure the research from the start, while helping to illustrate how science can serve communities in large and small ways. 
A similar intention guided our adaptive comanagement meetings at the end of the project, described later, where we shared project deliverables and led adaptive comanagement meetings to ground-truth and coproduce our research results and assumptions. The question of future community action based on any new scientific knowledge and resulting deliverables is in many ways ultimately outside our hands as researchers. However, participants in the final meetings reported the high value of and need for more dialogue and knowledge-sharing between community members themselves [20]. The opportunity to share data provides more than social capital and ethical currency for researchers; it can also help everyday people better understand how science works. Furthermore, these start-to-finish partnerships may help researchers create more usable science products for local participants [75].

\subsubsection{Assist Existing Community-Based Projects}

Historically positioned at the intersection of inquiry and social action, environmental justice movements are prominent examples of how participatory action research, community-based participatory research, action science, and community science can be used to engage and empower communities [76]. Researchers may find existing groups of citizens tackling local socioecological problems. Citizen science conceptualized as predominantly data collection ignores the alternative and diverse pathways for science to transverse across multiscalar and polycentric governance structures [66,77]. Researchers should resist the urge to compete with, consume, or even take over these existing groups. Instead, it is important to try to find a way to plug into the groups' goals and serve in an assistant capacity by providing needed resources.

In our project, we coordinated with the Union County Hydrology Project, an existing collaborative water monitoring project run by a local water and conservation district in response to declining water well levels in Northeastern New Mexico along the shared Texas border, where center pivot irrigation (CPI) is rampant [45]. In support of that project, we participated in data sharing and adjusted our research to complement their independent ongoing investigations with hydrogeologist Dr. Kate Zeigler mapping the geohydrology and withdrawal and recharge rates of the region [78]. The conservation district shared information concerning declining groundwater levels collected from local landowners. Based on their needs, a graduate student developed a project mapping CPI change in the region and consequent perceptions of individual- and community-level socioecological resilience [48]. As a result, we were able to share maps showing the growth and contraction of CPI systems from the 1950s to the present. Additionally, we collaborated in joint grant writing efforts which, regardless of success, served to increase the sense of partnership and led to invitations for annual presentations at Soil and Water Conservation District stakeholder meetings.

While this was not a direct goal of our initial project, we would be remiss to ignore the immense importance of cultural and social learning processes within the context of water resource management $[79,80]$, and the transmission of local traditional ecological knowledge (TEK) [81,82]. Vogel and colleagues [83] call for researchers to transcend traditional science approaches and find opportunities, similar to the Union County Hydrology Project, to connect science within steps of the community decision-making process. However, one must be careful of the power dynamics within these relationships and tread lightly so as not to limit resilience efforts. For us, cooperative dialogue with an existing citizen group enabled a more speedy delivery of products useful for local resilience-building activities, while also increasing trust in science and thus in our project. Although collaboration is time-consuming, it ultimately led to project benefits, as we were able to identify land users for drought adaptation surveys for a robust geographic sampling method.

\subsubsection{Find Niches for Project Participation, Technology Transfer and Education}

An important part of coproduction is building a platform for participation, both within and beyond formal institutions. Citizen science projects themselves are too often 
conceptualized and positioned as the formal platforms for participation and education [84]. Alternatively, researchers could seek out "niche" partnerships, defined as the local collaborators, leaders, and networks that can initiate and legitimize public participation [85]. We found that local museum partners were some of our most valuable "niche" contacts in terms of gaining a more well-rounded context for our research, finding additional community participants, and embedding ourselves in the places we work and study. Our research team contributed several small exhibits for local museums, including posters, pamphlets, and interpretive materials prepared by students as part of field research courses (more below). These approaches frequently made use of resources that were readily available at the museums, but could benefit from the added value of digitization, analysis, and interpretation. The possibilities for productive community partnerships and technology transfer are seemingly endless and include shared grant writing, technology training, and community mapping, among others.

Recently, we incorporated new technologies into our work, acknowledging that small museums may not have the skills or resources to produce digital versions of their resources or create online exhibits. One example was a project to digitize a partner museum's collection of county plats and use the resources for analysis in the emerging field of historic geographic information systems (HGIS). These dilapidated wall maps, which detailed the ownership of each parcel of land in the county annually, were stored in a corner of the museum without any interpretive materials or analysis. To realize the utility of these rich historical resources, we photographed or scanned them, digitized the parcel geometry and ownership data, and compiled the data in a geographic information system. Putting together a time series from multiple sources, we were then able to track changes in land ownership over time using robust statistical methods and analysis that would have been impossible without this work [49].

In our evolving and symbiotic relationship with our museum contacts, both parties saw benefits to our efforts. Our team produced presentations and publications related to the plat analysis, while also gaining additional context for our future research. For our museum partners, we were able to provide digital versions of the badly damaged plats and helped identify the production year for several maps that were not dated. Based on several rounds of feedback from community members and museum curators, we also produced an online mapping and interpretive application. Created using Esri's publicly available StoryMaps platform, our webmap delivered a narrative describing the origin of our study, examples of historical plats, and interactive graphs detailing our results (Figure 2). This and other interpretive applications produced using museum archives may be viewed at our project webpage: http://biosurvey.ou.edu/Grasslands/main.html (accessed on 29 December 2021).

Additionally, our project worked with three area museums to support the archiving of our completed oral histories, including the creation of transcripts and rescuing of museum oral histories from VHS and cassette tapes, and the digitization of historical Dust Bowl documents. In working with partners, we tried to remain open to requests, which often led us down surprising and serendipitous paths, such as the unexpected but complementary HGIS analysis of Dust Bowl Survivors. While museums and local historical societies proved to be our strongest allies, researchers seeking to employ PAR approaches could partner with any number of other local interest groups, libraries, societies, or non-profits. 


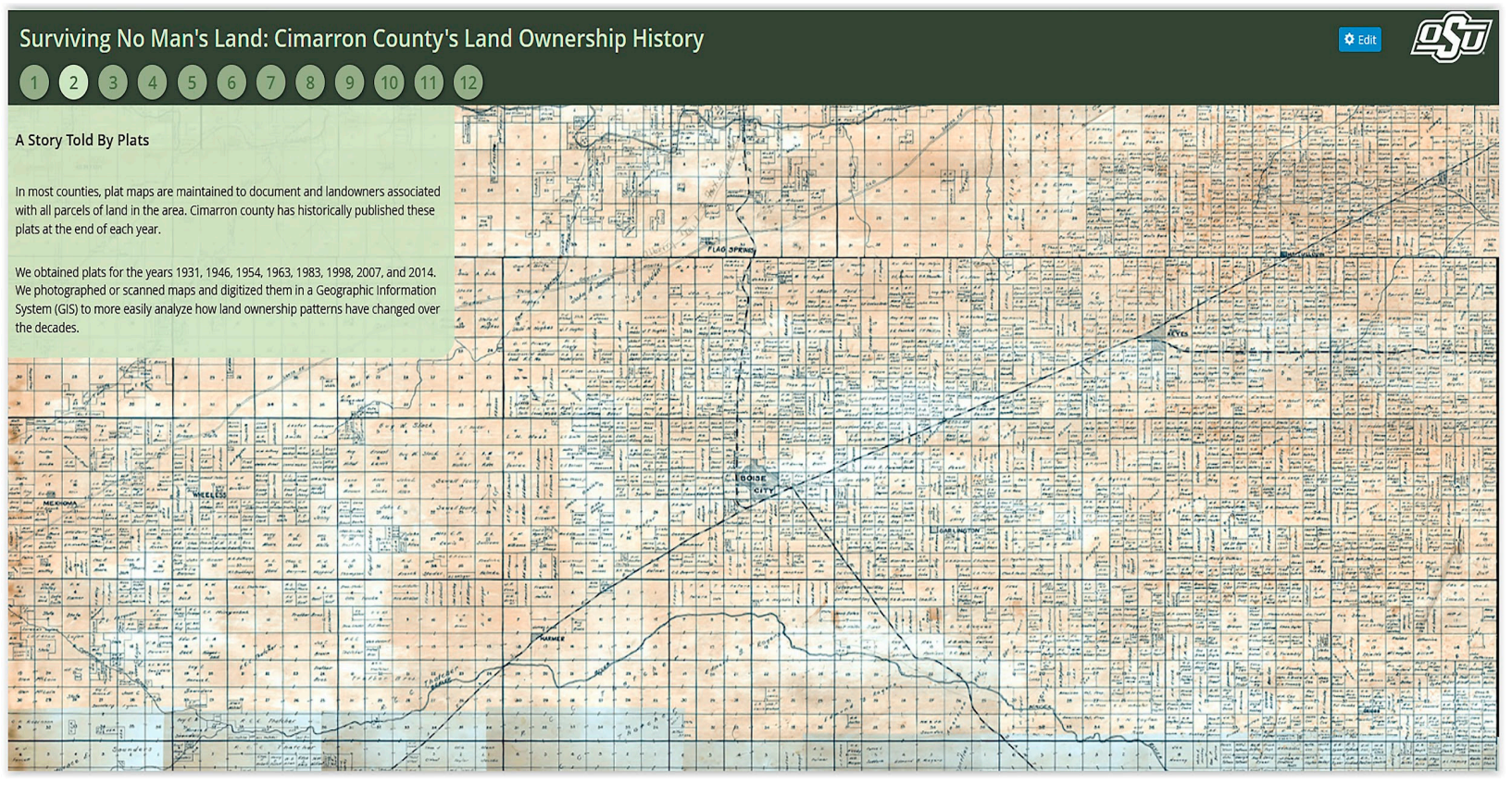

Figure 2. Example of online mapping and storytelling applications derived from museum archives to create a detailed history of land ownership in Cimarron County, Oklahoma. The publicly available website helps to add interpretive value to the Cimarron Heritage Center's collection of plat maps.

\subsubsection{Organize Student Field Projects}

Student research projects based on the expressed needs of residents and local institutions helped maximize our role in academic institutions while providing opportunities for future researchers to learn about PAR and transdisciplinary research. Research (e.g., [86,87]) indicates that students directly benefit from involvement in PAR, gaining a deeper understanding of theory through practice. Students involved in the coproduction of knowledge, for instance, must make theoretically informed decisions while confronting their own positions, values, and ethics [86]. Within the context of our research, students from mostly urbanized areas engaged with rural agriculturists to better understand vulnerability and resiliency in the face of adverse climatic extremes. Additionally, as Elwood [87] notes, among the most valuable lessons students gain through involvement in participatory research is learning to ethically work within different social, cultural, and political settings.

As part of a capstone course taught by the lead author, roughly 90 undergraduate and graduate students developed valuable experience in community-engaged research. In this process, we worked with communities to identify local research needs and capacity building. Based on challenges, problems, and/or questions identified by community members and local agencies, the students created mini-projects executed over the course of $6-8$ weeks during the semester. This arrangement produced meaningful collaborations, as citizens tend to be more available for students when they are heavily invested in the research results. However, such an approach also took considerable time to organize, requiring multiple side trips necessary to the study area both before and after the student projects were completed. Ultimately, this leads to the social capital notion of "mutual exploitation, mutually agreed upon" [88].

Over the past 10 years, our students participated in a wide range of related research projects including the archiving of oral histories, the digitization of valuable Dust Bowl museum archives, the creation of GIS Story Maps, historical walking tours, and tourist maps, among other things. While many of these research experiences for students might not directly answer our funded project's goals on socioecological resilience to drought, they did provide quick and meaningful deliverables to the communities where we worked with direct impacts on community resilience. For example, a walking tour map of historic 
WPA buildings did not relate directly to current drought adaptation. However, the map helped create support for the preservation of a local WPA-built school, while extrapolating on histories and symbols of historic drought resilience. This provided broader context and subtext to our research while at the same time growing social capital.

Students were able to experience the entire life cycle of participating in a small research project, while communities and local agencies received specific products and deliverables for their time. Relatedly, when the community picks the problem, they are more likely to talk to students and be more open and tolerant of the student learning process. Involving students in research projects also trains the next generation of scholars and researchers. These activities are valued by government funders, where we see increasing initiative for undergraduate research experiences. These small projects can be transformative in the way they challenge students to make decisions concerning how they communicate and provide room for error through experiential learning.

The result is data that is useful to the community, where the community gains a better understanding of the value of research. The effort to organize field research is tremendous (e.g., arranging housing, narrowing project scope, etc.) with lead researchers acting as "translators" between young scientists and communities. We argue that what might appear to be a tangential use of time and resources is actually a valuable ethical and communitycentered approach with transformative opportunities for both communities and the training of future researchers [89]. Answering the "so what" question to the community through related student projects is an entry point to fostering mutual respect, often absent in some citizen science approaches. Furthermore, the WPA student project led to the sharing of related Dust Bowl survivor stories that we would not have otherwise been aware of, which ultimately led to a more thorough understanding of resilience and collective memory. In sum, not only do student projects help teach students about the process of ethically engaged research, but they also build social capital at the research site. This extra social capital and community investment ultimately strengthens the quality and efficacy of the research process and results.

\subsubsection{Create Safe Spaces for the Discussion of "Hot Topics"}

PAR offers opportunities to explore alternative pathways for governance and capacity building that attend to issues of power, interest, and legitimacy embedded in water and land-use policy [66]. Building a web of relationships is the core effort or mechanism for coproduction between science and society. This means asking questions related to who calls participatory forums or invites stakeholders, who gets to speak, when, and who determines what is important or not when it comes to building socioecological resilience [90]. Water is an increasingly controversial topic in general. A recent US public attitudes survey, for instance, suggests public support for regulation, but not to the detriment of agriculture and the environment [91]. As researchers we might shy away from controversial topics for fear of project success or due to our own institutional pressures to avoid topics such as climate change. Hosting adaptive comanagement meetings can provide safe spaces for communities to discuss the complexities of socioecological problems. Consensus building is time-consuming and not guaranteed, but as our experience shows below, there are benefits to involving the community in interpreting the research results and deciding who gets to use the findings.

At four adaptive comanagement community meetings [92] representing 100 community households, we addressed land and water management and resilience issues with producers, focusing on how land tenure policy and differential groundwater government may influence resource management decisions and resultant lulcc dynamics (Figure 3). To prepare for the meetings, we held informal conversations at various venues with community members regarding what they saw as key issues of importance. Additionally, we received extensive input by community members into meeting times, locations, and other cultural norms and preferences for how to run the meetings. As a result of those discussions, we focused the community meetings on three main topics: perceptions and adaptations 
to risk hazards (invasive and nuisance plant species, flash flooding, drought, etc.), lulcc such as woody plant encroachment and CPI, and drought and climate perceptions and communication.

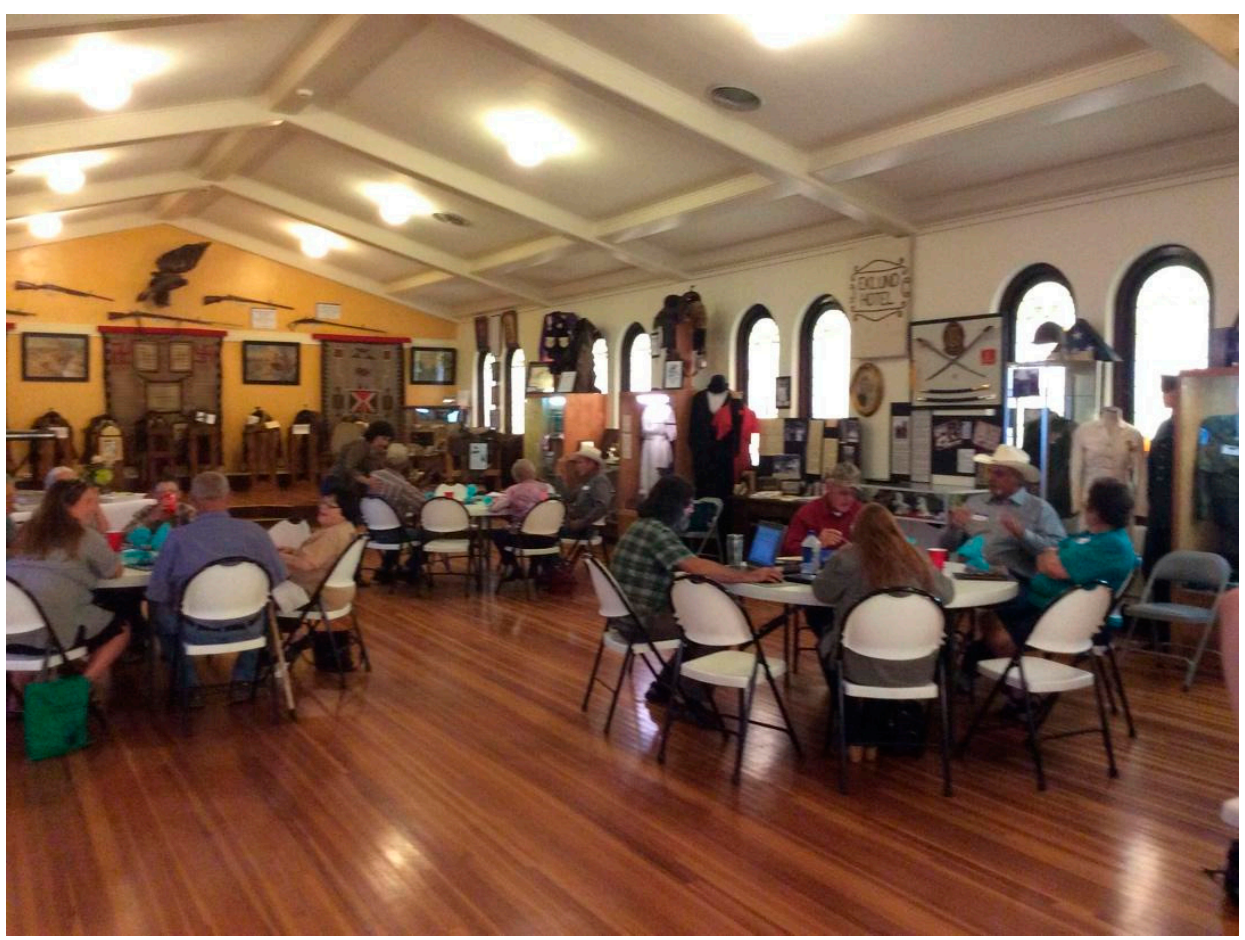

Figure 3. Small "table talk" scene from one of the adaptive comanagement community meetings.

We prepared four related hand-outs, as well as planned participatory mapping exercises (see Figures 4-6). For example, to discuss woody plant encroachment, we used research on lulcc conducted by the project team [51] as a springboard for discussion. We showed participants photographs of common nuisance and invasive species in the area, such as one-seed juniper (Juniperus monosperma), cholla (Cylindropuntia imbricata), mesquite (Prosopis glandulosa), bindweed (Convolvulus arvensis), locoweed (Atragalus spp.), and others. For each, we asked participants if they had any land management issues with the various species and, if so, the nature of the issues, how they coped with the issues, and whether they believed that state and/or federal land lease policies exacerbated issues with these species. Then, we showed the participants a series of lulcc maps illustrating both changes in woody plant (particularly cholla and one-seed juniper) distribution and growth and contraction of center pivot irrigation. Without leading participants, we asked them to interpret the results, while elaborating on their interpretations. These discussions led to coproduced results, where we used our science-produced products and their lived experiences to explore whether land-cover change dynamics (e.g., woody plant encroachment and loss of pastureland) could be linked to state and federal land leasing policies.

These meetings served multiple purposes, not only coproducing results, but also triangulating evidence and garnering better understanding of local TEK. We also gauged whether individual perceptions regarding these dynamics conformed to the actual processes, as observed from repeat satellite imagery and lulcc classifications. Conversations and activities explored the interface between local, regional, and state water governance and federal agriculture subsidies, such as crop-specific subsidies (e.g., corn) and conservationrelated government payments (e.g., EQIP), and resulting perceptions of vulnerability and resilience. By coproducing instead of simply presenting "our" results, we were able to have open and fluid dialog concerning "hot" and even highly controversial topics. 


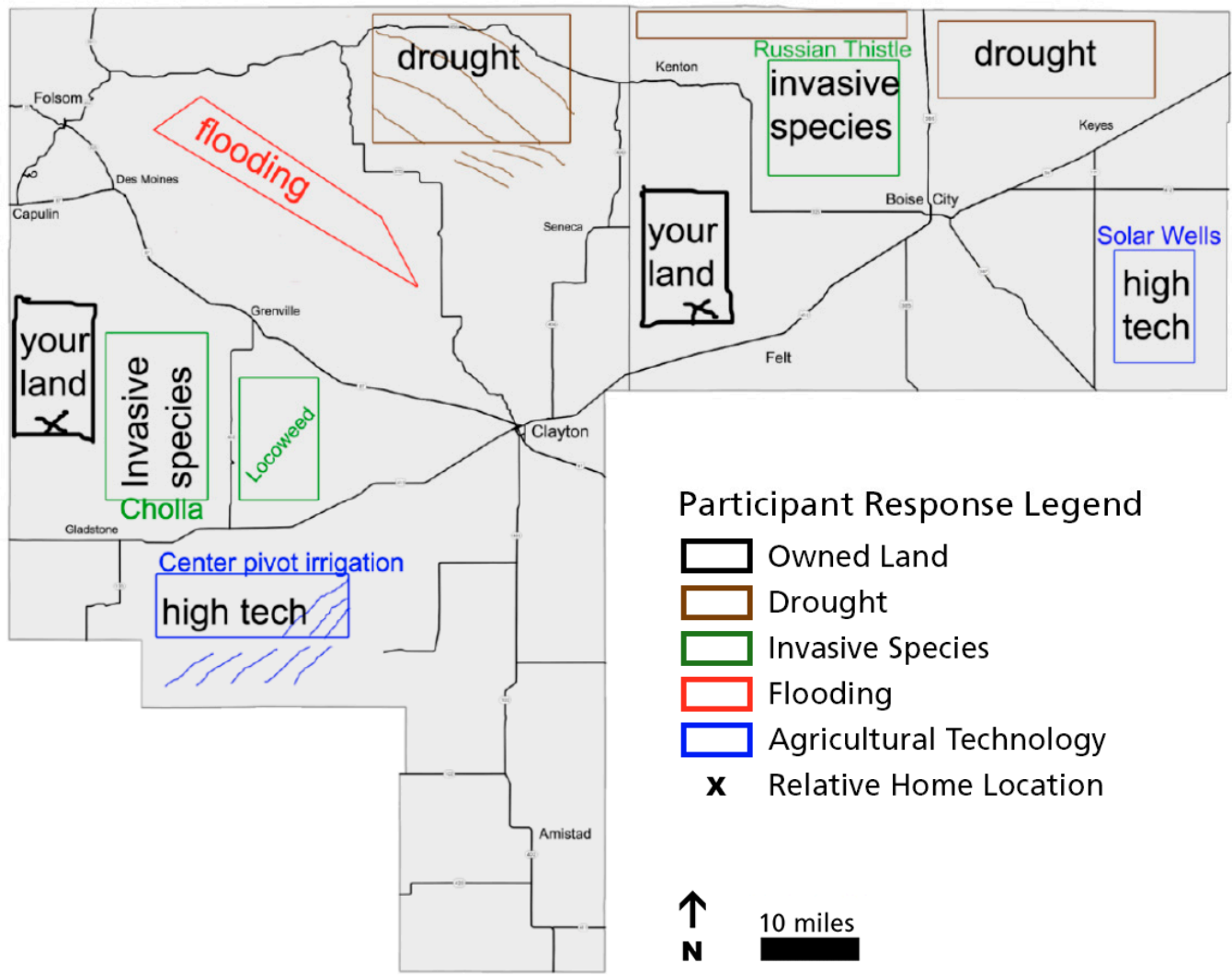

Figure 4. An example of a participatory sketch map.
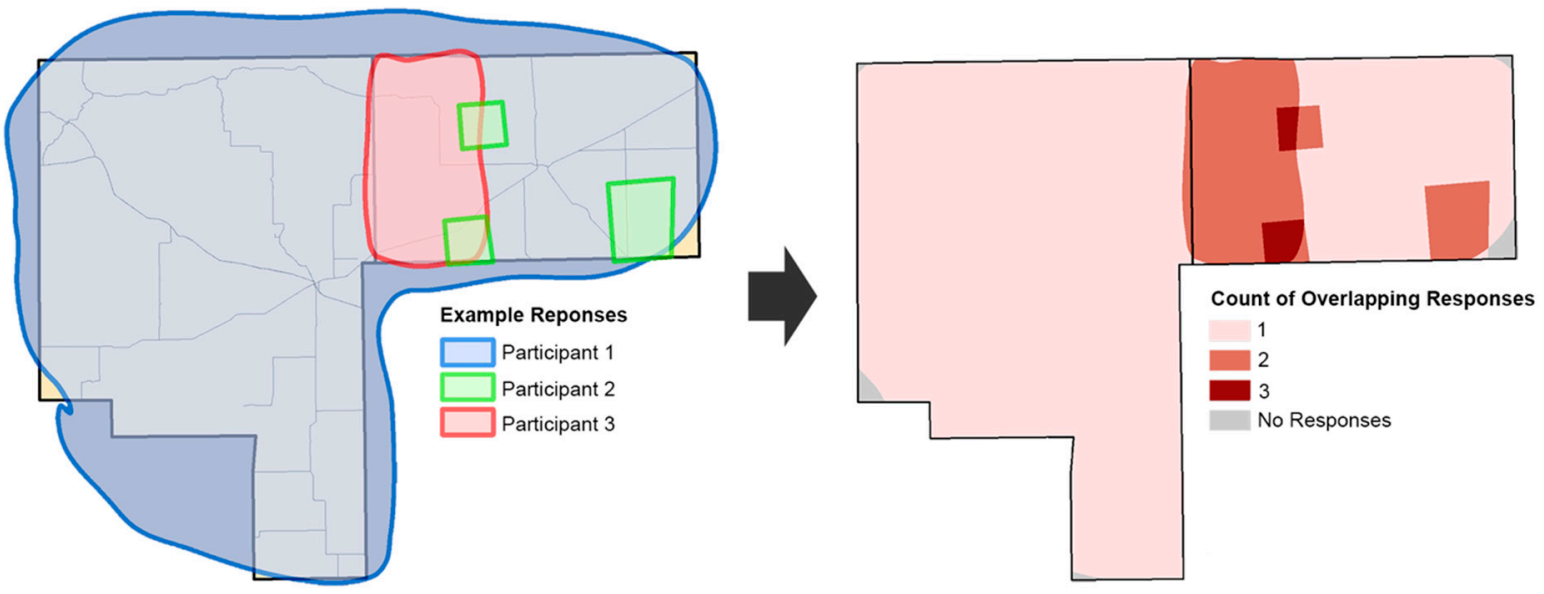

Figure 5. An example of TEK participant mapping of perceived environmental hazards. After participants marked environmental hazards on our paper map template, we scanned and digitized their responses (left). We then created composite choropleth maps, noting frequency, which helped us identify hotspots of participant responses (right). 

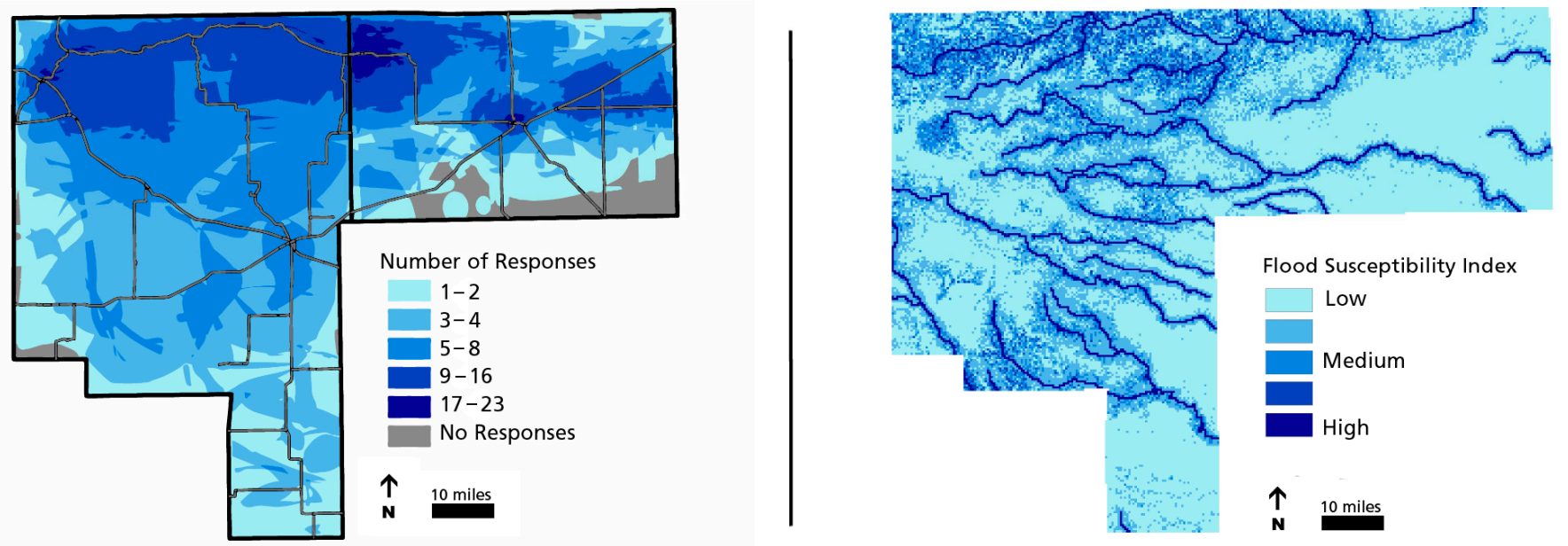

Figure 6. An example of a comparative composite TEK map: flood risk perceptions against a flood susceptibility index. The composite map created for flash flooding events allowed us to gain a better understanding of local perceptions regarding this hazard. In this high-resolution dataset, we observed that many cited the Dry Cimarron River corridor along the northern boundary of our study area and certain roadways in the east as problematic areas (left). We also compared participant responses $(n=200)$ to an index we created for flood susceptibility (right), finding many similarities between the two maps. We performed this process for a variety of local hazards based on community concerns.

Land tenure policy is a particularly sore topic, especially in Cimarron County, where competitive state land leasing policies have been shown to increase vulnerability, especially during periods of prolonged drought [50]. The adaptive comanagement meetings involving various members of the community provided a platform for producers to address a highly contentious issue with others experiencing similar situations. These discussions, coupled with the issue of nuisance species, provided a means for producers to explore the causes and consequences of tenure and land-use decisions, as related to land tenure policy, while providing the researchers with valuable insight of on-the-ground dynamics and vetting of the remote sensing-derived lulcc data products [51]. Furthermore, it allowed the results and interpretations of the analysis to be coproduced.

Similarly, the presentations on the growth and contraction of CPI provided a forum for producers to discuss another contentious issue, especially for producers in Union County. Whereas a large portion of Cimarron County is underlain by the HPA, only a small portion of eastern Union County is so underlain. Consequently, center pivot irrigation is more limited in Union County. More restrictive groundwater regulations in New Mexico further limit groundwater-based irrigation in Union County. Nonetheless, looser water pumping restrictions in neighboring Dallam County, TX, USA and Cimarron County, OK, USA, serve as a pressure point for Union County producers. Community meetings provided the producers an outlet to explore and discuss the relationship of CPI growth and contraction over time in relation to different levels of groundwater governance and incentivization, from local to national levels. It also gave them a safe space to discuss their growing needs and concerns regarding water security issues. Producers' insights provided us with valuable information on how differential governance impacts the decision-making process and resource management. As a result of these coproduction activities and others, we could ensure that local understandings and interpretations were included with our scientific map products, while also providing us with confidence that our own interpretations of the scientific results were, indeed, correct [48].

A voluntary exit survey and participant feedback $(n=42)$ aimed to capture individual perceptions concerning the value of the meeting and most important drought management tasks, as well as solicit recommendations for additional scientific inputs or policymaking strategies [20]. $79 \%$ of participants $(n=33)$ ranked the meetings of high value. In particular, participants noted the value of learning from each other (e.g., "We have resilient 
people, we are survivors" and "Everyone has the same problems we do"), as well as the value of science (e.g., "Universities are doing good research" and "There are people helping us to understand"). The results revealed the perceived value of and clear need for more opportunities for dialogue and knowledge-sharing among community members themselves.

The most important management issues identified by the community themselves included: cattle/grassland management, conservation/land stewardship, drought preparedness/response, water resource management, and nuisance pests/encroachment issues. While the meeting participants expressed a variety of definitions and frames for understanding drought impacts, very few expressed specific ideas for policy prescriptions or additional research. Overall, participants wanted policymakers to understand the uniqueness of their place/region, work to eliminate tensions with regulations and bureaucracy, address their "actual" needs as agriculturalists, and support policies for sustainable practices. These findings indicated the need for and utility of dynamic models for academic-community partnership capacity that could minimize the spatial and temporal gaps between research and decision-making processes. However, more important than solving their problems, participants expressed the value of having an inclusive, mutually respectful, and supportive forum in which to express themselves, listen, and share. Regardless of the topic a researcher might be studying, creating safe spaces to discuss "hot topics" is not only appreciated by the community members themselves but can also serve as a means for the researcher to better understand complex dynamics while serving as an opportunity to coproduce research results.

3.1.6. Use Participatory Mapping and Traditional Environmental Knowledge (TEK) Techniques for the Coproduction of Scientific Knowledge

Coproducing results with communities is important, especially in remote sensingbased studies where attempts at linking "people to pixels" have obvious cultural and scalar mismatches and challenges [93]. Building off of past PAR experiences in the Amazon [94], we recognized that traditional environmental knowledge (TEK) is often ignored by mainstream scientific approaches $[23,95]$. Tapping into TEK can help with community capacity and trust building, while also inverting the historical power dynamics often involved in scientific study [96]. Here, we realized that publicly available maps may not be readily available, be of high quality, or meet the specific needs of the research team or local communities. For example, FEMA does not produce flood maps for much of our study area. Road maps and online mapping services are notoriously inaccurate, particularly in sparsely populated areas. Furthermore, issues of scale or imperfect data products can lead to misleading or erroneous findings in research. This challenge was especially clear in our attempts to find fine-scale climate data in our study area. Many rural counties may only maintain one or two weather stations. Residents of our study area, though, frequently told us that weather patterns - particularly precipitation — are highly variable and spatially isolated, resulting in differential impacts on household vulnerability to drought.

We launched a participatory mapping project in which we asked members of the community to join us in creating maps depicting drought, flash flooding, invasive species encroachment, and other environmental hazards [97] (see Figures 4-6). Our research team frequently visited community events and public spaces with blank maps and colored pencils in hand, finding residents willing to share their knowledge. Although participants were often tentative at first, believing that they were not "experts," we reassured them that their qualifications as local residents gave them expertise that transient researchers or remote sensors inherently lacked. We asked participants to draw on our map templates, using a different color to indicate different types of environmental hazards (Figure 4). We then scanned participant maps, digitized them, created a geographic information system (GIS) (Figure 5), and produced composite maps representing commonalities among 200 participant responses (Figure 6). This allowed us to identify broad trends or "hazard hotspots." 
In addition to the obvious result of gathering data to help explain spatial patterns of environmental hazards, we also found several tangential benefits. First, interacting with the community helped us build social capital as we met new people and promoted awareness of our research. Second, participatory mapping served as a great conversation starter, allowing us to gain a better understanding of potentially unforeseen hazards and other directions for our research. Third, because the mapping exercise was easy to learn and conduct, it gave several undergraduate students the opportunity to visit the field and gain research experience. Lastly, and arguably most importantly, participatory mapping empowered communities to know that their knowledge and input were important, efficacious, and valuable. This helps to promote positive perceptions of science and research, as well as a greater sense of human agency to identify and respond to hazards in their own environment. We presented the results comparing the "maps of the people" next to the results from our scientific data-driven models (see Figure 6) at several community and local meetings. In more cases than not, the maps showed significant overlap. Furthermore, more often than not, people thanked us for making the maps. One resident lamented about the frequent mistreatment by many researchers and agency representatives who come to their communities as the "experts" to tell them what is going on with their natural resources and what they should do about it, stating: "Thank you for treating us as equals. We know we know a lot about what's going on out here, and you just gave us the proof that we do." Critically trained geographers using participatory mapping techniques can work with grassroots organizations to generate science products that speak to, for, and with communities for social and environmental justice-oriented action [98].

\subsubsection{Create Tools for the Community, by the Community, with the Community}

Data, information, and technology are key components for community engagement in scientific research [99]. In addition to starting with and investing in community concerns, it is important to also consider the uses and impacts of our geographic tools. There is an iterative process of developing ideas from user needs and improving the products through iteration. With more technology and data available, we need to find ways to use these tools to speak not just within our disciplines but across subareas and within vulnerable communities [100]. The utility of our tools for landowners and farmers improves the quality of our research, but also becomes a vehicle for driving community conversations and planning. Science, and especially citizen science, is a process with social components and the usability of tools should come from a codesign perspective. High levels of engagement in process and product are necessary to avoid the "crowdharvesting" of participants as a resource rather than as full collaborators [100].

To this end, we developed a number of information tools, including a project website (http:/ / biosurvey.ou.edu/Grasslands / main.html, accessed on 29 December 2021) and a series of web-based mapping tools, for the dissemination of the various project data. The project website provides general information regarding the project to various stakeholders, with additional links to related projects. It also serves as a portal to tools designed to assist in decision-making processes. Diverse stakeholders have access to published reports and journal articles, project factsheets, tourism documents, and research posters and presentations, all of which are designed to assist in the decision-making process on a range of topics.

In addition to the Story Maps, we produced two interactive web map applications related to lulcc dynamics in the area, both of which were based on research conducted in the area [51] and vetted at the adaptive comanagement meetings. The first interactive map (http://arcg.is/24uBfzJ, accessed on 29 December 2021) allows users to view the land-cover characteristics of Cimarron County, OK and Union County, NM in 1992 and 2011, respectively. With this interactive map, users can use a slider bar to view changes in land cover, such as woody vegetation cover that has reduced available grasslands for cattle forage. Additionally, tools are provided to enable users to search for specific locations (e.g., $\mathrm{X}, \mathrm{Y}$ coordinates, an address, or a town). The map also provides basic navigation, 
such as zoom and panning, for individuals to manually search the map, and a print to view function.

While the basic interactive map enables users to view land-cover characteristics of Cimarron and Union counties, the second viewer (http:/ / arcg.is/2nQaNNQ, accessed on 29 December 2021) expands the functionality of the map viewer and adds an additional data layer, land tenure, so that users can view the land-cover dynamics in conjunction with spatial information on state and federal lands. More specifically, this map provides a number of tools to assist in the land management process: a draw palette, for instance, provides users with annotation tools to add points, lines, polygons, and text to the map; measurement tools enable the user to calculate the approximate distance or area of select features; a print tool permits users to create digital (e.g., PDF or JPG) or hardcopy prints of maps and annotations; navigational and search tools permit users to find their current location, other locations, and to explore the map at different scales; layer control tools enable users to toggle various data layers on and off, to swipe the layers to see changes over time, and to change basemaps; and sharing tools permit individuals to share the map and even embed it on their own websites.

While these interactive tools were designed specifically for use by members of the communities, they were designed and redesigned based on feedback from local residents to increase their utility and usability. We discussed these tools regularly at local meetings through both formal and informal processes, providing a means for individuals to provide feedback. Producers on the ground understand the lulcc dynamics at a local level that is not attainable via traditional remote sensing products. Based on their feedback, we were able to increase the utility and power of these tools. Errors of omission and commission can occur even with the best data classifications and there will always be a degree of inaccuracy. By providing producers with these data products and tools in regular dialog, individuals can vet the accuracy of the land-cover classification based on their own experiences and provide us with the necessary feedback to improve our data products. While at times their requests were beyond the scope of our research team's expertise, we found that the effort needed to learn a new technology or programming language was well worth the overall benefit in terms of creating a product that would actually be used. Furthermore, these efforts built social capital and trust between the researchers and the communities.

\subsubsection{Share First, Decide Together What Is Shared and What Is Not}

Engagement with citizens should be seen as a repetitive, reflexive process, not a one-time activity [22]. We must carefully consider that the way we share information with communities may not be how we share the data with the world. In this project, we considered the ethics of deciding how oral histories were accessed and used. The interviewees were given many options on the release form to share their video, audio, or just transcript, and the rights to edit the transcript. In terms of privacy and access, they also decided where the oral history would be stored in the local museum or on-line, or to participate without sharing or archiving.

At a broader dissemination level, there are important ethical considerations to efforts to make citizen science data publicly accessible. For example, while our Story Maps included data that were publicly accessible, the community chose not to put these online for public use. The ease of accessibility and the power of a GIS changes the power dynamics of how information might be used by others in both positive and negative ways. There are often tensions between the open data initiatives of funding agencies and the ethical obligations to communities. Innocuous choices and bad data management can have real impacts on communities [17]. It is an ethical choice to share data with the community and beyond, but we also need to honor their choices regarding how and where to share that information.

\subsubsection{Do Not Be a Beverly Hills Geographer/Researcher-Just Say "Yes!"}

In his now famous field methods syllabus, renowned cultural ecologist and anthropologist Bernie Nietschmann [101] reminded his students to contemplate the power dynamics 
wrapped around ethnography. For Nietschmann [101], research often is performed on, or imposed upon, remote, powerless, and/or marginalized people. By asking us to imagine actually succeeding in an ethnographic household survey in Beverly Hills, he reminds us to contemplate the inherent power dynamics involved in the research process, pointing out that marginalized groups and the most vulnerable people might not feel that they can say "no." As a result of these traditional power dilemmas between the researcher and the researched, our PAR approach sincerely tries to break down these binaries and take a just say "yes" stance when it comes to requests from the communities we work with as well as our local institutional partners.

At times, saying "yes" means extra work on our end (the student-based project experiences above help with this matter). Sometimes, this means the commitment of extra time and/or resources. Sometimes, it means driving seven hours mid-semester to give a one-hour talk during the Annual Dust Bowl museum fundraiser, only to turn around and drive back seven more hours. It often seems more practical to say no, but remembering these inherent power dynamics gives us a sincere pause in contemplating community related requests. Sometimes we are not able to meet a specific request, but we may be able to use other available resources such as small grants to accomplish some of these tasks. In other cases where the request is considerable, such as mapping the growth and contraction of CPI, it might take time to get a graduate student to take on the project. Part of our PAR approach means making a long-term commitment to the study area. Regardless, just making a concerted effort to invert some of the inherent power dynamics involved in the inherent process of doing scientific research leads to social capital, trust building, and good will on our part, and sometimes it even leads to the generation of new ideas that greatly advance our science (such as our historic GIS analysis, see [49]).

\subsubsection{Reflect on the Process, Adapt as Needed}

Introducing participatory methods into citizen science requires constant adaptation and reflexivity. Although research methods are often fixed due to funding limitations or logistical constraints [102], we found success in gradually developing and optimizing our processes by employing modern project management practices [103] and the iterative approaches common in PAR [104]. These principles, such as those described in Lean Six Sigma or the Deming Cycle, advocate for starting small, learning quickly, and rapidly iterating to develop processes efficiently [105]. The types of engagements described in this article could not be completely planned in advance or on a tight schedule, but rather evolved from committed effort, reflection, and adaptation on our part as researchers working in partnership with communities. Discussions with community partners, as well as community meetings of various sorts, happened iteratively throughout the project. Regular check-ins were required as a project evolved. Working collaboratively in partnership with communities required staying open to serendipity, even when it felt as though it was working against you or your objectives.

For instance, when we first started working in our study area, there was a sense of urgency to capture the drought stories of older people before they died. This perceived urgency by local residents drove much of our initial community collaboration through our commitment to record, transcribe, and share substantially more oral histories than the initial small set. Although only part of our research project, the oral histories could, at times, "feel" as though they were initially interfering with completing (or even starting) our other research objectives. In the beginning, such delays could be stressful to the broader research team, particularly graduate students or early career faculty on a rigid timeline, where the community's wants might seem to be in conflict with individual researcher needs and aspirations. At the same time, the oral histories opened more doors to us than any community meetings and other standard recruiting strategies ever did. In truth, everyone in the study area has or knows a grandparent, great aunt or uncle, or family friend that survived the Dust Bowl. Furthermore, many of the community-led student projects, while often appearing somewhat divergent to start, intersected with the larger context of 
rural economic decline and the preservation of town culture that supports resilience in "droughthy" times. These smaller projects informed the changing face of irrigation, land ownership, and other human dimensions of drought.

A commitment to reflexivity led to shifting priorities and adjusting schedules based on community wants and priorities. Such a commitment helped us gain trust, while also expanding our community network. In this sense, taking time to complete components of perceived importance to the local community helped us with other aspects of our research project, such as the socioecological vulnerability and lulcc components. As a result of prioritizing community preferences, the communities gained more trust in science and scientists, which greatly bolstered our own team and individual research objectives.

The complexity and situationality of environmental problems demands that such work be iterative, reflexive, and adaptive to the changing realities and needs of local communities. For a researcher with a deadline and expected deliverables, the prospects of such work can be scary, uncertain, and hard. However, we believe such work can also unleash the liberatory potential of citizen science.

\section{Conclusions}

We offered 10 entry points for incorporating participatory approaches for a more robust citizen science approach to socioecological and sustainability systems research. We argue that participatory methods are complementary to citizen science and, taken together, can lead to more robust results and stronger communities. PAR's people-centered approach leads to better science through increased participation and greater confidence in the accuracy and interpretation of the results, such as our lulcc analysis. Incorporating ethics as a core operating principle, PAR focuses on equitable exchange rather than extraction. As such, it is also, in part, deliverable-oriented in approach in extremely utilitarian ways. This leads to quickly "usable" results for local communities, long before the traditional route of dissemination via the publication of academic manuscripts. Consequently, PAR approaches lead to the production of strong social capital and greater community buy-in. While many of our scientific publications focused primarily on more technical methods such as remote sensing [48,94], UAS [52], lulcc modeling [51], or household survey results [47], we argue that the participatory components outlined here remain the "unsung hero" that allowed us to successfully and ethically continue to be productive in our study sites, including the continued enrollment and participation in our related citizen science projects (see https: / / arid.nmsu.edu/ and http:/ / www.spottyrain.org/, accessed on 29 December 2021) for more information). We, therefore, see participatory approaches as not only complementary to citizen science, but also a key means for growing and maintaining community involvement.

At the same time, there are several disadvantages of using a PAR approach. In fact, many of the road-tested strengths of PAR approaches are also weaknesses. For instance, PAR can be quite slow to practice in reality, because it requires sustained commitment and constant reflexivity. Furthermore, this process can make such research costly, especially in terms of time. Seeing communities as equitable partners requires flexibility from all parties as the wants, needs, and priorities of diverse stakeholders might change. Such changes can derail one's research in divergent (or, we argue, even delightful) ways. At the same time, consensus building can be difficult [42]. For a researcher, a PAR approach might seem at odds with the traditional academic reward structure which privileges peer-reviewed research outputs over community-driven research deliverables. Furthermore, a researcher operating in a more traditional science paradigm might find themselves at odds with a community's own paradigm and/or traditional knowledge system.

The promise of citizen science rests in the reconciliation of the often dueling ideals of ethical community-centered design and more robust science. PAR approaches have a long history (50+ years) and offer an expanded, ethically-just, field-tested tool kit for researchers to draw upon to foster more robust academic-community partnerships and beyond. In comparison, being a much more recent development, the field of citizen science is just 
catching up. Synthesized into 10 entry points for more ethical and participatory science, our semi-chronological narrative offers concrete strategies at various stages of socioecological research and highlights the place-based, ethical, and methodological contexts for applying each strategy. While strategies for every research project will be different, the core approach is "open-minded" or "solidarity science" that conducts science with people, for people [30]. Incorporating such approaches, we contend, is not only a matter of doing more robust socioecological research, but also of ensuring environmental and social justice.

Author Contributions: Conceptualization, J.M.V., N.M.C., T.D.F. and A.L.B.; methodology, J.M.V., N.M.C., T.D.F., A.L.B. and B.B.; fieldwork, research, and analysis; J.M.V., N.M.C., T.D.F., A.L.B. and B.B.; writing-original draft preparation, J.M.V., N.M.C., T.D.F., A.L.B. and B.B.; writing-review and editing, J.M.V., N.M.C., T.D.F. and A.L.B.; visualization, T.D.F. and A.L.B.; supervision, J.M.V.; project administration, J.M.V.; funding acquisition, J.M.V., N.M.C. and T.D.F. All authors have read and agreed to the published version of the manuscript.

Funding: This manuscript is based upon work supported by the National Science Foundation under grants CMMI \#1266381 and SMA\#1415368. Further funding in support of the participatory and citizen science approaches used in this project has been made possible by support through the USDA (AFRI 2018-68002-28109) and NSF (DRL\# 1811506). Jacqueline M. Vadjunec's work on this article was supported, in part, by the National Science Foundation (NSF) while she was working at the Foundation.

Institutional Review Board Statement: The study was conducted according to the guidelines of the Declaration of Helsinki, and approved by the Institutional Review Board of Oklahoma State University (AS-12-60, 20 March 2017 and AS-18-24 7 May 2019).

Informed Consent Statement: Informed consent was obtained from all subjects involved in the study.

Data Availability Statement: Related data, results, and publications discussed in this article can be found at the following project websites: https: / biosurvey.ou.edu/Grasslands/main.html, http: / / www.spottyrain.org/ and https://arid.nmsu.edu/index.html, (accessed on 29 December 2021).

Acknowledgments: We are grateful to our colleagues, students, and the community members acting in support of this project. Furthermore, we thank our funders (above) for their generous support. Additionally, the authors thank the special issue editors and three anonymous reviewers for their helpful feedback. Any opinions, findings, conclusions, or recommendations expressed here are those of the authors alone and do not necessarily reflect the views of others acknowledged here.

Conflicts of Interest: The authors declare no conflict of interest. The funders had no role in the design of the study; in the collection, analyses, or interpretation of data; in the writing of the manuscript, or in the decision to publish the results.

\section{References}

1. Irwin, A. Citizen Science: A Study of People, Expertise, and Sustainable Development; Routledge: London, UK, 1995.

2. Irwin, A.; Wynne, B. Misunderstanding Science?: The Public Reconstruction of Science and Technology; Cambridge University Press: Cambridge, UK, 2004.

3. Bonney, R.; Cooper, C.B.; Dickinson, J.; Kelling, S.; Phillips, T.; Rosenberg, K.V.; Shirk, J. Citizen science: A developing tool for expanding science knowledge and scientific literacy. BioScience 2009, 59, 977-984. [CrossRef]

4. Cooper, C.B.; Dickinson, J.; Phillips, T.; Bonney, R. Citizen science as a tool for conservation in residential ecosystems. Ecol. Soc. 2007, 12, 11. Available online: http:/ / www.ecologyandsociety.org/vol12/iss2/art11/ (accessed on 30 June 2021).

5. Shirk, J.L.; Ballard, H.L.; Wilderman, C.C.; Phillips, T.; Wiggins, A.; Jordan, R.; McCallie, E.; Minarchek, M.; Lewenstein, B.V.; Krasny, M.E.; et al. Public participation in scientific research: A framework for deliberate design. Ecol. Soc. 2012, 17, 29. [CrossRef]

6. Adamou, A.; Georgiou, Y.; Paraskeva-Hadjichambi, D.; Hadjichambis, A.C. Environmental citizen science initiatives as a springboard towards the education for environmental citizenship: A systematic literature review of empirical research. Sustainability 2021, 13, 13692. [CrossRef]

7. Turreira-García, N.; Lund, J.F.; Domínguez, P.; Carrillo-Anglés, E.; Brummer, M.C.; Duenn, P.; Reyes-García, V. What's in a name? Unpacking "participatory" environmental monitoring. Ecol. Soc. 2018, 23, 24. [CrossRef]

8. Theobald, E.J.; Ettinger, A.K.; Burgess, H.K.; DeBey, L.B.; Schmidt, N.R.; Froehlich, H.E.; Wagner, C.; HilleRisLambers, J.; Tewksbury, J.; Harsch, M.A.; et al. Global change and local solutions: Tapping the unrealized potential of citizen science for biodiversity research. Biol. Conserv. 2015, 181, 236-244. [CrossRef]

9. Skarzauskiene, A.; Mačiulienè, M. Citizen science addressing challenges of sustainability. Sustainability 2021, 13, 13980. [CrossRef] 
10. Future Earth 2012. Available online: https:/ / futureearth.org/ (accessed on 30 June 2021).

11. The United Nations Educational, Scientific and Cultural Organization (UNESCO). UNESCO Science Commission Adopts Open Science Recommendation. 2021. Available online: https:/ / council.science/current/news/unesco-science-commission-adoptsopen-science-recommendation/ (accessed on 29 December 2021).

12. Hecker, S.; Haklay, M.; Bowser, A.; Makuch, Z.; Vogel, J.; Bonn, A. Innovation in Open Science, Society, and Policy-Setting the Agenda for Citizen Science. In Citizen Science: Innovation in Open Science, Society, and Policy; Hecker, S., Haklay, M., Bowser, A., Makuch, Z., Vogel, J., Bonn, A., Eds.; UCL Press: London, UK, 2018; pp. 1-23.

13. Schade, S.; Pelacho, M.; Noordwijk, T.; Vohland, K.; Hecker, S.; Manzoni, M. Citizen Science and Policy; Springer: New York, NY, USA, 2021. [CrossRef]

14. Sui, D.; Goodchild, M.; Elwood, S.A. Volunteered geographic information, the exaflood, and the growing digital divide. In Crowdsourcing Geographic Knowledge; Sui, D., Elwood, S.A., Goodchild, M., Eds.; Springer: Dordrecht, The Netherlands, 2013; pp. 1-12.

15. Purdam, K. Citizen social science and citizen data? Methodological and ethical challenges for social research. Curr. Sociol. 2014, 62, 374-392. [CrossRef]

16. Mah, A. Environmental justice in the age of big data: Challenging toxic blind spots of voice, speed, and expertise. Environ. Sociol. 2017, 3, 122-133. [CrossRef]

17. Colston, N.; Vadjunec, J.M.; Wakeford, T. Exploring the entry points for citizen science in urban sustainability initiatives. Curr Opin. Environ. Sustain. 2015, 17, 66-71. [CrossRef]

18. Wiggins, A.; Crowston, K. From conservation to crowdsourcing: A typology of citizen science. In Proceedings of the 44th Hawaii International Conference on System Sciences, Kauai, HI, USA, 4-7 January 2011; pp. 1-10. [CrossRef]

19. Crall, A.W.; Newman, G.J.; Stohlgren, T.J.; Holfelder, K.A.; Graham, J.; Waller, D.M. Assessing citizen science data quality: An invasive species case study. Conserv. Lett. 2011, 4, 433-442. [CrossRef]

20. Colston, N.; Vadjunec, J.M.; Fagin, T.D. What is the role of academic-community partnership capacity in adaptive drought communication? Lessons from open public meetings. In Proceedings of the Citizen Science Association Conference, Twin Cities, MI, USA, 17-20 May 2017.

21. Soleri, D.; Long, J.W.; Ramirez-Andreotta, M.D.; Eitemiller, R.; Pandya, R. Finding pathways to more equitable and meaningful public-scientist parternships. Citiz. Sci. Theory Pract. 2016, 1, 1-11. [CrossRef]

22. Wainwright, J. Geopiracy: Oaxaca, Militant Empiricism, and Geographical Thought; Palgrave Macmillan: New York, NY, USA, 2012.

23. Haklay, M. Citizen science and volunteered geographic information: Overview and typology of participation. In Crowdsourcing Geographic Knowledge; Springer: Dordrecht, The Netherlands, 2013; pp. 105-122.

24. Dickinson, J.L.; Bonney, R. Citizen Science: Public Collaboration in Environmental Research; Cornell University Press: Ithaca, NY, USA, 2012.

25. Wisner, B.; Stea, D.; Kruks, S. Participatory and action research methods. In Advances in Environment, Behavior, and Design; Zube, E.H., Moore, G.T., Eds.; Springer: New York, NY, USA, 1991; pp. 271-295.

26. De Andrade, E.N.F.; da Cunha, N.V. Action research with John Dewey's poetic and rhetoric pedagogy. Int. J. Action Res. 2017, 13, 261-275. [CrossRef]

27. Lewin, K. Action research and minority problems. J. Soc. Issues 1944, 2, 34-46. [CrossRef]

28. MacDonald, C.D. Understanding participatory action research: A qualitative research methodology option. Can. J. Action Res. 2012, 13, 34-50.

29. Freire, P. Pedagogy of the Oppressed; Herder and Herder: New York, NY, USA, 1970.

30. Maguire, Patricia. Doing Participatory Research: A Feminist Approach. Center for International Education, Amherst, MA. Available online: https:/ / scholarworks.umass.edu/cie_participatoryresearchpractice/6 (accessed on 29 December 2021).

31. Hildebrand, P.E.; Ruano, S. El Sondeo: Una Metodología Multidisciplinaria de Caracterización de Sistemas de Cultivo Desarrollada por el ICTA; Folleto Técnico-Instituto de Ciencia y Tecnología Agrícolas-ICTA: Villa Nueva, Guatemala, 1982.

32. Posey, D.A.; Dutfield, G.; Plenderleith, K. Collaborative research and intellectual property rights. Biodivers. Conserv. 1995, 4, 892-902. [CrossRef]

33. Harding, S. The Postcolonial Science and Technology Studies Reader; Duke University Press: Durham, UK, 2011.

34. Athayde, S.; Silva-Lugo, J.; Schmink, M.; Kaiabi, A.; Heckenberger, A. Reconnecting art and science for sustainability: Learning from indigenous knowledge through participatory action-research in the Amazon. Ecol. Soc. 2017, 22, 36. [CrossRef]

35. Pimbert, M.; Wakeford, T. Prajateerpu, power and knowledge: The politics of participatory action research in development part 1. Context Proc. Safeguards Action Res. 2003, 1, 184-207. [CrossRef]

36. Anderson, B.; Böhmelt, T.; Ward, H. Public opinion and environmental policy output: A cross-national analysis of energy policies in Europe. Environ. Res. 2017, 12, 114011. [CrossRef]

37. Rocheleau, D. Maps, numbers, text, and context: Mixing methods in feminist political ecology. Prof. Geogr. 1995, 47, 458-466. [CrossRef]

38. Poteete, A.R.; Janssen, N.; Ostrom, E. Working Together: Collective Action, the Commons, and Multiple Methods in Practice; Princeton University Press: Princeton, NJ, USA, 2010. [CrossRef]

39. Blaikie, P.; Cannon, T.; Davies, I.; Wisnerm, B. At Risk: Natural Hazards, People's Vulnerability and Disaster; Routledge: London, UK, 2004.

40. McCall, M.; Peters-Guarin, G. Participatory action research and disaster risk. In The Routledge Handbook of Hazards and Disaster Risk Reduction; Wisner, B., Kelman, I., Gaillard, J.C., Eds.; Routledge: London, UK, 2012; pp. 727-741. 
41. Flicker, S.; O'Campo, P.; Monchalin, R.; Thistle, J.; Worthington, C.; Masching, R.; Guta, A.; Pooyak, S.; Whitebird, W.; Thomas, C. Research done in "A Good Way": The importance of indigenous elder involvement in HIV community-based research. Am. J. Public Health 2015, 105, 1149-1155. [CrossRef]

42. Smith, L.; Bratini, L.; Chambers, D.-A.; Jensen, R.V.; Romero, L. Between idealism and reality: Meeting the challenges of participatory action research. Act. Res. 2010, 8, 407-425. [CrossRef]

43. Grant, J.; Nelson, G.; Mitchell, T. Negotiating the challenges of participatory action research: Relationships, power, participation, change, and credibility. In The SAGE Handbook of Action Research, 2nd ed.; Reason, P., Bradbury, H., Eds.; SAGE Publications Ltd.: London, UK, 2008; pp. 588-601.

44. Harrison, J.L. Parsing "Participation" in Action Research: Navigating the challenges of lay involvement in technically complex participatory science projects. Soc. Nat. Resour. 2011, 24, 702-716. [CrossRef]

45. Paris, D.; Winn, M.T. Humanizing Research: Decolonizing Qualitative Inquiry with Youth and Communities; Sage Publication Ltd.: London, UK, 2014.

46. Vadjunec, J.M.; Frazier, A.E.; Kedron, P.; Fagin, T.D.; Zhao, Y. A land systems science framework for bridging land system architecture and landscape ecology: A case study from the southern high plains. Land 2018, 7, 27. [CrossRef]

47. Colston, N.M.; Vadjunec, J.M.; Fagin, T.D. It is always dry here: Examining perceptions about drought and climate change in the southern high plains. Environ. Commun. 2019, 13, 958-974. [CrossRef]

48. Wegner, K.; Vadjunec, J.M.; Fagin, T.D. Groundwater governance and the growth of center pivot irrigation in Cimarron County, OK and Union County, NM: Implications for community vulnerability to drought. Water 2017, 9, 39. [CrossRef]

49. Vadjunec, J.M.; Boardman, A.; Fagin, T.D.; Larson, M.P.; Kedron, P.; Birchler, B. Footprints from the dust bowl: Using historical geographic information systems to explore land and resource access, use, and survivability in "No Man's Land," Cimarron County, Oklahoma. Ann. Am. Assoc. Geogr. 2021, 111, 1906-1930. [CrossRef]

50. Vadjunec, J.M.; Sheehan, R. Ranching and state school land in cimarron county, Oklahoma. Great Plains Res. 2010, $20,163-177$.

51. Fagin, T.D.; Vadjunec, J.M.; Colston, N.M.; Wegner, K.; Graham, A. Land tenure and landscape change: A comparison of public-private lands in the southern great plains. Ecol. Proc. 2016, 5, 12. [CrossRef]

52. Boardman, A. The Next Generation of Land System Science: Integrating Meso-Scale Analysis and UAS Remote Sensing in Changing Plant Communities of the United States' Southern Great Plains. Master's Thesis, Oklahoma State University, Stillwater, OK, USA, 2020.

53. Duncan, D.; Burns, K. The Dust Bowl: An Illustrated History; Chronicle Books LLC: San Francisco, CA, USA, 2012.

54. Egan, T. The Worst Hard Times; Houghton Mifflin Company: Boston, MA, USA, 2006.

55. U.S. Drought Monitor. U.S. Drought Monitor, 2021. Available online: http:/ /droughtmonitor.unl.edu/ (accessed on 28 September 2018).

56. Alvis, B.N. A history of Union County. N. M. Hist. Rev. 1947, 22, 256.

57. Young, N.G. Cimarron County. The Encyclopedia of Oklahoma History and Culture. 2018. Available online: www.okhistory.org (accessed on 26 September 2018).

58. Lowitt, R. American Outback; Texas Tech University Press: Lubbock, TX, USA, 2006.

59. United States Census Bureau. QuickFacts. 2021. Available online: https://www.census.gov/quickfacts/fact/table/US/PST04521 7 (accessed on 28 March 2021).

60. The Nature Conservancy (TNC). Oklahoma Black Mesa Nature Preserve. 2018. Available online: https://www.nature.org/enus/get-involved/how-to-help/places-we-protect/black-mesa-preserve/ (accessed on 28 September 2018).

61. United States Department of Agriculture (USDA). 2017 Census of Agriculture, 2017. Available online: https://www.nass.usda. gov / Publications / AgCensus/2017/index.php (accessed on 28 March 2021).

62. Turner, B.; Meyer, W.B.; Skole, D.L. Global land-use/land-cover change: Towards an integrated study. Ambio 1994, 23, 91-95.

63. Pfeiffer, L.; Lin, C.-Y.C. Does efficient irrigation technology lead to reduced groundwater extraction?: Empirical evidence. J. Environ. Econ. Manag. 2014, 67, 189-208. [CrossRef]

64. Environmental Working Group (EWG). Farm Subsidies Database, 2020. Available online: https:/ /www.ewg.org/ (accessed on 30 June 2021).

65. Mauser, W.; Klepper, G.; Rice, M.; Schmalzbauer, B.S.; Hackmann, H.; Leemans, R.; Moore, H. Transdisciplinary global change research: The co-creation of knowledge for sustainability. Curr. Opin. Environ. Sustain. 2013, 5, 420-431. [CrossRef]

66. Van Kerkhoff, L.E.; Lebel, L. Coproductive capacities: Rethinking science-governance relations in a diverse world. Ecol. Soc. 2015, 20, 14. [CrossRef]

67. Godemann, J.; Michelsen, G. Sustainability communication-An introduction. In Sustainability Communication; Springer: Dordrecht, The Netherlands, 2011; pp. 3-11.

68. Heinrichs, H. Participation: Empowerment for sustainable development. In Sustainability Communication; Springer: Dordrecht, The Netherlands, 2011; pp. 187-198.

69. Von Korff, Y.; d'Aquino, P.; Daniell, K.A.; Bijlsma, R. Designing participation processes for water management and beyond. Ecol Soc. 2010, 15. Available online: http:/ / www.ecologyandsociety.org/vol15/iss3/art1/ (accessed on 28 March 2021). [CrossRef]

70. Stevens, M.; Vitos, M.; Altenbuchner, J.; Conquest, G.; Lewis, J.; Haklay, M. Taking participatory citizen science to extremes. IEEE Pervasive Comput. 2014, 13, 20-29.

71. Minkler, M. Ethical challenges for the "outside" researcher in community-based participatory research. Health Educ. Behav. 2004, 31, 684-697. [CrossRef] 
72. Pandya, R.E. A framework for engaging diverse communities in citizen science in the US. Front. Ecol. Environ. 2012, 10, $314-317$. [CrossRef]

73. Israel, B.A.; Schulz, A.J.; Parker, E.A.; Becker, A.B. Review of community-based research: Assessing partnership approaches to improve public health. Ann. Rev. Public Health 1998, 19, 173-202. [CrossRef]

74. Huntington, H.P. Using traditional ecological knowledge in science: Methods and applications. Ecol. Appl. 2000, 110, 1270-1274. [CrossRef]

75. Prokopy, L.S.; Carlton, J.S.; Haigh, T.; Lemos, M.C.; Mase, A.S.; Widhalm, M. Useful to Usable: Developing usable climate science for agriculture. Climat. Risk Manag. 2017, 15, 1-7. [CrossRef]

76. Bacon, C.; deVuono-Powell, S.; Frampton, M.L.; LoPresti, T.; Pannu, C. Introduction to empowered partnerships: Communitybased participatory action research for environmental justice. Environ. Justice 2013, 6, 1-8. [CrossRef]

77. Ostrom, E.; Cox, M. Moving beyond panaceas: A multi-tiered diagnostic approach for social-ecological analysis. Environ. Conserv. 2010, 37, 451-463. [CrossRef]

78. Zeigler, K.E.; Podzemny, B.; Yuhas, A.; Blumenberg, V. Groundwater resources of Union County. N. M. A Prog. Rep. N. M. Geol. Soc. Guideb. 2019, 70, 127-137.

79. Beierle, T.C. Public Participation in Environmental Decisions: An Evaluation Framework Using Social Goals. Resources for the Future 1998. Available online: http:/ /ageconsearch.umn.edu/bitstream/10497/1/dp990006.pdf (accessed on 30 June 2021).

80. Pahl-Wostl, C.; Tàbara, D.; Bouwen, R.; Craps, M.; Dewulf, A.; Mostert, E.; Taillieu, T. The importance of social learning and culture for sustainable water management. Ecol. Econ. 2008, 64, 484-495. [CrossRef]

81. Berkes, F.; Colding, J.; Folke, C. Rediscovery of traditional ecological knowledge as adaptive management. Ecol. Appl. 2000, 10, 1251-1262. [CrossRef]

82. Benyei, P.; Aceituno-Mata, L.; Calvet-Mir, L.; Tardío, J.; Pardo-de-Santayana, M.; García-del-Amo, D.; Rivera-Ferre, M.; MolinaSimón, M.; Gras-Mas, A.; Perdomo-Molina, A.; et al. Seeds of change: Reversing the erosion of traditional agroecological knowledge through a citizen science school program in Catalonia, Spain. Ecol. Soc. 2020, 25, 19. [CrossRef]

83. Vogel, C.; Moser, S.C.; Kasperson, R.E.; Dabelko, G.D. Linking vulnerability, adaptation, and resilience science to practice: Pathways, players, and partnerships. Glob. Environ. Chang. 2007, 17, 349-364. [CrossRef]

84. Stepenuck, K.F.; Green, L. Individual- and community-level impacts of volunteer environmental monitoring: A synthesis of peer-reviewed literature. Ecol. Soc. 2015, 20, 19. [CrossRef]

85. Moellenkamp, S.; Lamers, M.; Huesmann, C.; Rotter, S.; Pahl-Wostl, C.; Speil, K.; Pohl, W. Informal participatory platforms for adaptive management. Insights into niche-finding, collaborative design and outcomes from a participatory process in the rhine basin. Ecol. Soc. 2010, 14, 41. [CrossRef]

86. Pain, R. Commentary: Working across distant spaces: Connecting participatory action research and teaching. J. Geogr. High. Educ. 2009, 33, 81-87. [CrossRef]

87. Elwood, S.A. Integrating participatory action research and GIS education: Negotiating methodologies, politics and technologies. J. Geogr. High. Educ. 2009, 33, 51-65. [CrossRef]

88. Robbins, P. Research is theft: Environmental inquiry in a postcolonial world. In Approaches to Human Geography; Aitken, S., Valentine, G., Eds.; SAGE Publications Ltd.: London, UK, 2006; pp. 311-324.

89. Vadjunec, J.M. A place for serendipitous mistakes? Selling mixed methods fieldwork to students in a digital age. Geogr. Rev. 2019, 110, 23-37. [CrossRef]

90. Rocheleau, D. Political ecology in the key of policy: From chains of explanation to webs of relation. Geoforum 2008, 39, 716-727. [CrossRef]

91. Stoutenborough, J.W.; Vedlitz, A. Public attitudes toward water management and drought in the United States. Water Resour. Manag. 2014, 28, 697-714. [CrossRef]

92. Plummer, R.; Crona, B.; Armitage, D.R.; Olsson, P.; Tengö, M.; Yudina, O. Adaptive comanagement: A Systematic review and analysis. Ecol. Soc. 2012, 17, 11. [CrossRef]

93. Liverman, D.; Moran, E.F.; Rindfuss, R.R.; Stern, P.C. People and Pixels: Linking Remote Sensing and Social Science; National Academy Press: Washington, DC, USA, 1998.

94. Vadjunec, J.M.; Rocheleau, D. Beyond forest cover: Land use and biodiversity in rubber trail forests of the Chico Mendes Extractive Reserve. Ecol. Soc. 2009, 14, 29. Available online: http://www.ecologyandsociety.org/vol14/iss2/art29/ (accessed on 30 June 2021). [CrossRef]

95. Gaillard, J.-C.; Maceda, E.A. Participatory three-dimensional mapping for disaster risk reduction. Particip. Learn. Act. 2009, 60, 109-118.

96. Lakshminarayanan, S. Using citizens to do science versus citizens as scientists. Ecol. Soc. 2007, 12, r2. Available online: http:/ / www.ecologyandsociety.org/vol12/iss2/resp2/ (accessed on 30 June 2021). [CrossRef]

97. Birchler, B.; Vadjunec, J.M.; Boardman, A.; Fagin, T.D.; Kedron, P. Mapping vulnerability to hazards and the effects of technology on building socio-ecological resilience in America's Southern High Plains. In Proceedings of the American Association of Geographers, Boston, MA, USA, 5-9 April 2017.

98. Boll-Bosse, A.J.; Hankins, K.B. “These Maps Talk For Us:” participatory action mapping as civic engagement practice. Prof. Geogr. 2018, 70, 319-326. [CrossRef]

99. Smith, W.J., Jr. Geographic research in water resources: A vibrant research agenda for the next 20 years. J. Contemp. Water Res. Educ. 2009, 142, 83-88. [CrossRef] 
100. Breen, J.; Dosemagen, S.; Warren, J.; Lippincott, M. Mapping grassroots: Geodata and the structure of community-led open environmental science. ACME Int. J. Crit. Geogr. 2015, 14, 849-873.

101. Nietschmann, B.Q. The Nietschmann syllabus: A vision of the field. Geogr. Rev. 2001, 91, 175-184. [CrossRef]

102. Lobe, B.; Vehovar, V. Towards a flexible online mixed method design with a feedback loop. Qual. Quant. $2009,43,585-597$. [CrossRef]

103. Mustaro, P.N.; Rossi, R. Project management principles applied in academic research projects. Issues Inform. Sci. Inf. Technol. 2013, 10, 325-340. [CrossRef]

104. Simonsen, J.; Hertzum, M. Iterative participatory design. In Design Research: Synergies from Interdisciplinary Perspectives; Simonsen, J., Bærenholdt, J.O., Büscher, M., Scheuer, J.D., Eds.; Routledge: London, UK, 2010; pp. 16-32.

105. Bhuiyan, N.; Baghel, A. An overview of continuous improvement: From the past to the present. Manag. Decis. 2005, 43, 761-771. [CrossRef] 